\title{
STUDY ON CARDIOVASCULAR MONITORING AND DIAGNOSIS OF ATHLETES
}

ESTUDO DEMONITORAMENTO CARDIOVASCULAREDIAGNÓSTICO DE ATLETAS

ESTUDIO DEMONITOREO CARDIOVASCULAR YDIAGNÓSTICO DEATLETAS

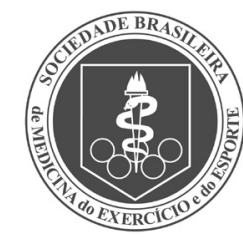

Original Article

Artigo OrigINAL Artículo Original

\author{
Zhangbo Xiao' (DD \\ (Physician) \\ Chang Sun² (DD \\ (Physical Education Professional), \\ Jie Bai' (D) \\ (Physician) \\ Xingjiang $\mathrm{Li}^{3}$ (ID \\ (Physician)
}

1. The Second Affiliated Hospital, Qiqihar Medical University, Qiqihar, Heilongjiang, China.

2. Department of Health and Care, Qiqihar Institute of Engineering,

Qiqihar, Heilongjiang, China.

3. Pathology College, Qiqihar Medical University, Qiqihar, Heilongjiang, China.

\section{Correspondence}

Xingjiang Li

Qiqihar, Heilongjiang, China,

161000.1xjphd@qmu.edu.cn

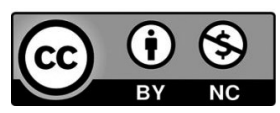

\begin{abstract}
Introduction: The study and collection of athletes' heart function index parameters and the correct and reasonable evaluation of body functions can effectively adjust training plans and avoid athletes' bodily exhaustion. Objective: To study the diagnosis of myocardial injury by cardiovascular monitoring in athletes from two aspects: extraction of characteristic parameters of heart function and research of signal processing. Methods: The heart function intelligent evaluation algorithm was studied by using multi-source information fusion, and embedded technology; miniature sensors were used as well. Results: The incidence of severe ventricular arrhythmia was lower in both groups. The incidence of sinus arrhythmia and intermittent second degree I atrioventricular block in the high-intensity group was significantly higher than that in the control group. The number of atrial and ventricular premature beats was lower in the control group, but increased significantly in the high-intensity group. Conclusions: This study applied the theory of multi-source information fusion to carry out representative research on the intelligent monitoring and evaluation of the heart function of elite athletes, centering on the application requirements of the heart function monitoring of elite athletes. Level of evidence Il; Therapeutic studies - investigation of treatment results.
\end{abstract}

Keywords: Heart Function Tests; Biological Monitoring; Damage Assessment.

\section{RESUMO}

Introdução: O estudo e a coleta de parâmetros indiciais da função cardíaca em atletas e a avaliação correta e razoável das funções corporais podem, efetivamente, levar ao ajuste de planos de treinamento e evitar a sobrecarga física de atletas. Objetivo: Estudar o diagnóstico da lesão miocárdica pelo monitoramento cardiovascular em atletas a partir de dois aspectos: a extração de parâmetros característicos da função cardíaca e a pesquisa do processamento de sinais. Métodos: O algoritmo de avaliação inteligente da função cardíaca foi estudado usando a fusão de informações de múltiplas fontes, além da tecnologia embarcada. Sensores em miniatura também foram usados. Resultados: A incidência de arritmia ventricular severa era menor nos dois grupos. A incidência de arritmia sinusal e o bloqueio atrioventricular de segundo grau do tipo I intermitente no grupo de alta intensidade foi significativamente mais alta do que no grupo de controle. $O$ número de batidas prematuras atriais eventriculares era menor no grupo de controle, mas aumentava consideravelmente no grupo de alta intensidade. Conclusões: Este estudo aplicou a teoria da fusão de informações de múltiplas fontes para conduzir uma pesquisa importante sobre o monitoramento e avaliação inteligentes da função cardíaca de atletas de elite, enfocando as exigências de aplicação do monitoramento da função cardíaca de atletas de elite. Nível de evidência Il; Estudos terapêuticos - investigação de resultados de tratamento.

Descriptores: Testes de Função Cardíaca; Monitoramento Biológico; Avaliação de Danos.

\section{RESUMEN}

Introducción: El estudio y la recogida de parámetros indíciales de la función cardíaca en atletas y la evaluación correctay razonable de las funciones corporales pueden efectivamente llevar al ajuste de planes de entrenamiento y evitar la sobrecarga física de atletas. Objetivo: Estudiar el diagnóstico de la lesión miocárdica a través del monitoreo cardiovascular en atletas a partir de dos aspectos: la extracción de parámetros característicos de la función cardíaca y la investigación del procesamiento de señales. Métodos: El algoritmo de evaluación inteligente de la función cerebral se estudió utilizando la fusión de informaciones de múltiples fuentes, además de la tecnología embebida. Sensores en miniatura también se utilizaron. Resultados: La incidencia de taquicardia ventricular severa era menor en los dos grupos. La incidencia de arritmia sinusal y bloqueo auriculoventricular de segundo grado del tipo I intermitente en el grupo de alta intensidad fue significativamente más alta que en el grupo de control. El número de contracciones prematuras auriculares y ventriculares era menor en el grupo de control, pero aumentaba considerablemente en el grupo de alta intensidad. Conclusiones: Este estudio aplicó la teoría de la fusión de informaciones de múltiples fuentes para conducir una investigación importante sobre el monitoreo y evaluación inteligentes de la función cardiaca de atletas de élite, centrando las exigencias de aplicación del monitoreo de la función cardíaca de atletas de élite. Nivel de evidencia ll; Estudios terapéuticos - investigación de resultados de tratamiento.

Descriptores: Pruebas de Función Cardíaca; Monitoreo Biológico; Evaluación de Daños. 


\section{INTRODUCTION}

With the development of modern sports competition, the monitoring of athletes' physical functions has become a key factor in the scientific formulation of training plans. Coaches can grasp the physical functions of athletes in time, prevent excessive fatigue and avoid accidental injuries, so as to reasonably adjust training programs and improve competition results. ${ }^{1}$ Heart function plays an indispensable role in a number of body function data, so it is necessary to make scientific diagnosis and evaluation of athletes' heart health. intensity exercise is still not clear, let alone effective protective measures. ${ }^{2}$

Through literature research, this paper expounds the relationship between marathon and cardiovascular system from three aspects of the adaptability, risk and risk screening of cardiovascular system, so as to give full play to the fitness benefits of marathon and avoid risk factors, so as to provide theoretical basis for better promoting the development of marathon. ${ }^{3}$

\section{METHOD}

\section{Experimental subjects}

In order to further try, the main objects of this study are the athletes from Qiqihar University,Qiqihar Medical University and Qiqihar Institute of Engineering who are preparing for the 2022 Heilongjing University Student Sports Meeting. The basic information of the athletes is shown in Table 1.4

It should be noted that there are three key technologies in this study. One is the research on intelligent evaluation algorithm of heart function based on multi-source information fusion, the second is the correct selection of sensors and signal design. The third is the design of the wireless interface between the overdraft alarm system and the communication terminal. The system can be miniaturized by using embedded technology and miniature sensors. The main technical route adopted in this study is shown in Figure 1. Firstly, the information fusion algorithm is designed with the help of fuzzy clustering theory, Bayesian theory and neural network, etc. Secondly, the characteristic parameters of heart function are obtained by using ECG sensor, pulse sensor and respiration sensor, etc, then, the heart function monitoring model was established by combining the two, and the heart function monitoring model was improved by comprehensively using evaluation indexes and evaluation methods, and the intelligent monitoring and evaluation system of the heart function of elite athletes was finally built. ${ }^{5}$

Table 1. Basic information table of athletes.

\begin{tabular}{c|c|c|c|c}
\hline number of people & Age & Body Weight $(\mathbf{k g})$ & Height $(\mathbf{c m})$ & Training years \\
\hline 22 & $20.34 \pm 2.23$ & $56.23 \pm 5.23$ & $172.43 \pm 4.23$ & $2.13 \pm 0.56$ \\
\hline
\end{tabular}

Among them, the theoretical research mainly includes the heart function intelligent evaluation algorithm of multi-source information fusion, the digital heart function index monitoring system, the physical overdraft alarm system and so on. In general, the formula for the fusion of multiple basic probability numbers is as follows:

$$
m(A)=\left\{\frac{\sum_{\cap A_{i}=A} \prod_{i=1}^{n} m_{i}\left(A_{i}\right)}{1-\sum_{\substack{\cap \\ A_{i}=\Phi}} \prod_{\substack{n \\ i=1}}^{n}\left(A_{i}\right)}, \forall A \subseteq \Theta, A \neq \Phi\right.
$$

Where, $A$ is the focus element, $M(A)$ is the basic probability number of $A$, which can be understood as the precise trust of $A, \Phi$ is an empty set. $A$ diagnostic evaluation model based on D-S evidence theory and BP neural network, athletes' heart conditions can be collected by several portable ECG sensors, and relevant characteristic parameters can be extracted after filtering and preprocessing, as the input condition of BP neural network, and then through the D-S evidence theory for fusion analysis, the basic probability assignment and the trust function are calculated to determine the trust interval, so as to make the diagnosis and finally give the evaluation result. ${ }^{6}$

The experiment selected 22 athletes' heart function parameters as samples, and the analysis model proposed in this paper. The accuracy of the evaluation results is shown in Table 2 .

\section{RESULTS}

Subjects in both groups were male, and there was no significant difference in baseline data between the two groups ( $P>0.05)$. (Table 3) All the subjects voluntarily participated in the project and signed the informed consent before the implementation of the project. Members

Table 2. Comparison of evaluation results of several models.

\begin{tabular}{c|c}
\hline Model source & Evaluation result accuracy is (\%) \\
\hline Document5 & 84.25 \\
\hline Document7 & 82.36 \\
\hline Document8 & 85.63 \\
\hline this text & 87.23 \\
\hline
\end{tabular}

Table 3. Comparison of baseline data between the two groups.

\begin{tabular}{c|c|c}
\hline & High Strength Group $(\mathbf{n}=\mathbf{1 0 0})$ & Control group $(\mathbf{n}=\mathbf{7 0})$ \\
\hline Age & $21.40 \pm 2.98$ & $20.65 \pm 2.54$ \\
\hline Body Weight $(\mathrm{kg})$ & $176.26 \pm 5.32$ & $175.56 \pm 7.56$ \\
\hline Height $(\mathrm{cm})$ & $72.56 \pm 5.69$ & $71.26 \pm 5.89$ \\
\hline
\end{tabular}

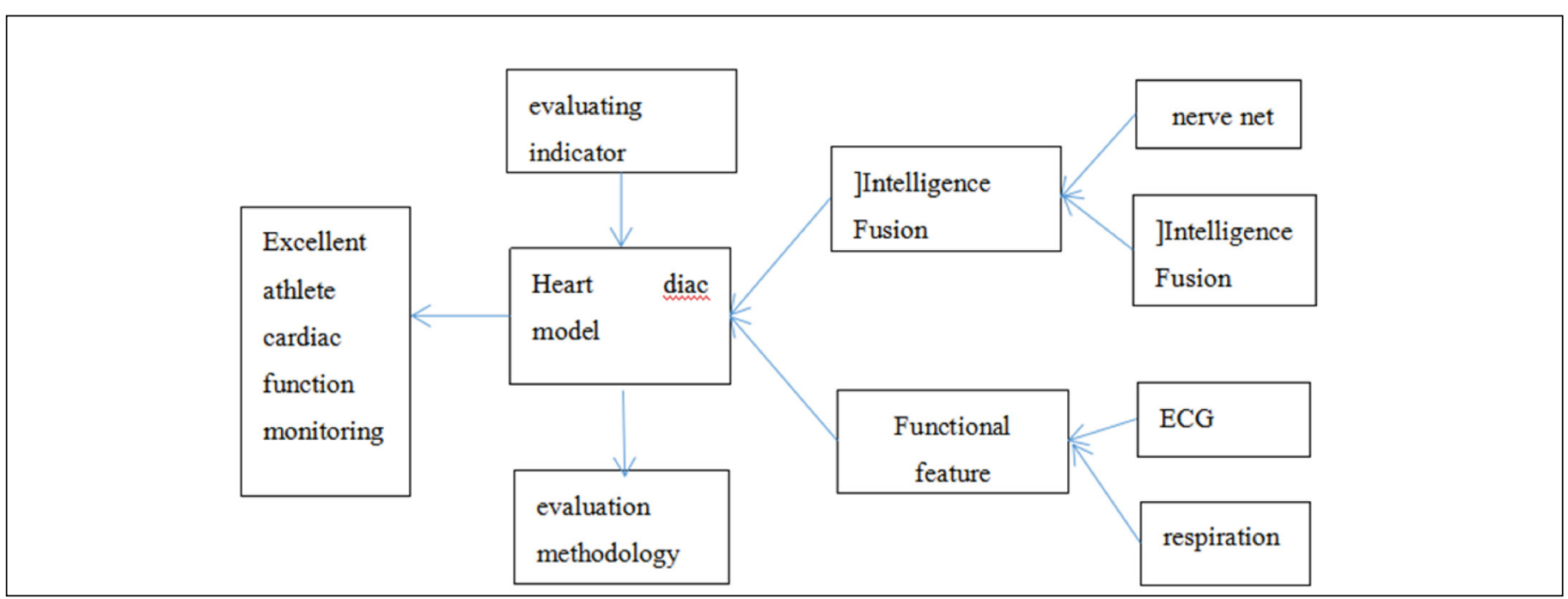

Figure 1. The main technical route adopted in this subject. 
of the research group were responsible for publicizing and informing the main content, purpose and significance of the study. High-intensity military training was conducted for a total of 3 days, blood collection and 24h dynamic electrocardiogram monitoring were performed the next day after the training.

Forty people were randomly selected from the high-intensity group, and 36 people were randomly selected from the control group. A total of 76 dynamic ECG samples were monitored for 24 hours on the next day after the end of high-intensity military training. The 12-lead synchronous dynamic electrocardiogram analysis system and heart rate variability analysis system were used for statistical analysis of ECG data. The average recording time of the high-intensity group was $23.25 \pm 1.27 \mathrm{~h}$, and that of the control group was $22.56 \pm 1.89 \mathrm{~h}$, and there was no statistically significant difference between the two groups $(P>0.05)$. $^{8}$

In this study, the analysis results of ECG electrophysiological changes of the two groups of subjects showed that the time-domain parameters of heart rate variability were significantly decreased in the high-intensity group, it is suggested that high intensity exercise can lead to cardiac autonomic nervous disorder and imbalance of sympathetic and parasympathetic nerve regulation, which leads to an increase in the incidence of arrhythmia in the high intensity group compared with the control group, the overall increased heart rate is prone to a series of cardiac electrophysiological changes such as sinus arrhythmia, intermittent second degree type I atrioventricular block, atrial premature beats and increased severity of ventricular premature beats.

\section{DISCUSSION}

The results showed that the serum cTnl levels in 8 of 12 male endurance athletes exceeded the clinical threshold value of $0.05 \mathrm{ug} / \mathrm{ml}$ for myocardial injury after $21 \mathrm{~km}$ running, and recovered to normal $24 \mathrm{~h}$ after running. The remaining 4 subjects' serum cTnl did not exceed the threshold of myocardial injury during the same period. In addition, troponin-negative athletes had longer training years and better aerobic exercise capacity than troponin-positive athletes. This trend is consistent with the results of the full-marathon running experiment conducted by foreign scholars on adult subjects. The trend of cTnl changes was significantly different from that of acute myocardial infarction in clinical Settings. In patients with acute myocardial infarction, serum cTnl appears in the serum 4 hours after obvious chest pain and remains abnormal for 5 to 7 days, with a maximum duration of up to 14 days. The criteria for determination of myocardial reversible and irreversible damage were based on the research report published by Ishikawa et al. in the journal ClinicalChemistry and the relevant contents in Pathology edited by Wu Zhongbi. Histology: reversible myocardial injury is characterized by a degenerative change characterized by a significant increase in abnormal or normal substances in cardiomyocytes or interstitium, the changes of myocardial nucleus, such as nuclear concentration, fragmentation and nucleolysis, were the main markers to determine the irreversible myocardial injury. Ultrastructural characteristics: The disintegration of mitochondria was used as the main marker to determine the irreversible myocardial injury. ${ }^{9}$

A comparison of TRIMP(training stimulus) and post-exercise peak cTnl showed consistent changes. In the $10 \mathrm{~km}$ exercise group, the TRIMP of $10 \mathrm{~km}$ run was significantly lower than that of $21 \mathrm{~km}$ run, and the same change was that the serum peak cTnl of $10 \mathrm{~km}$ run was significantly lower than that of $21 \mathrm{~km}$ run after exercise. In the $30 \mathrm{~km}$ exercise group, there was an increasing trend of TRIMP between the $30 \mathrm{~km}$ run and the $21 \mathrm{~km}$ run, but the difference was not statistically significant. The consistent change was that the serum peak cTnl after exercise also had an increasing trend between the $30 \mathrm{~km}$ run and the $21 \mathrm{~km}$ run, but the difference was not statistically significant. Therefore, exercise load may be an important factor in determining serum cTnl level after exercise.

Athletes in the process of heavy load training and recovery, endocrine system will have obvious changes. Serum testosterone is an important index to evaluate the functional status of athletes. Cortisol is an important hormone that promotes catabolism. When the serum cortisol level remains high after exercise, it will lead to excessive catabolism of the body, which is not conducive to eliminating fatigue. Overtraining may occur if the concentration is maintained at a high level for a long time without returning to normal. Preexercise cortisol and testosterone/cortisol ratio were positively and negatively correlated with post-exercise serum cTnl level, respectively, and the differences between the two indexes were significant, suggesting that the participants with higher cortisol and lower testosterone/cortisol ratio were more likely to have higher post-exercise serum cTnl level. ${ }^{10}$

\section{Differences between clinical and myocardial troponin I ele- vation after exercise}

First, myocardial troponin I increased clinically. When the cTnI value reached $0.09 \mathrm{ug} / \mathrm{ml}$, it indicated myocardial injury. When the cTnl value reached $0.5 \mathrm{ug} / \mathrm{ml}$, it indicated acute myocardial infarction, is irreversible damage to the heart muscle, and when cTnl rises after exercise, it drops back to normal within 24 hours, it is a reversible injury, and only if it does not decrease to normal level after 24 hours can it be considered as a clinical myocardial injury.

Second: duration, can remain abnormal in clinical $5 \sim 7$ days, the longest can last up to 14 days or so. They return to normal within 24 hours after exercise. Third, the elevation of cTnl in clinical practice will produce clinical symptoms, but no clinical symptoms after exercise. Fourth, elevated cTnl may clinically cause myocardial injury, unstable angina pectoris, and even myocardial infarction. It's life-threatening. However, the elevation of cTnl after exercise does not result in myocardial injury, and it will automatically recover after a certain period of rest.

\section{CONCLUSION}

A large number of literature shows that the research on monitoring athletes' heart function has always been a hot spot. In competitive sports, the average heart rate intensity of most athletes is $85 \%$, however, the performance of heart rate intensity is closely related to age, gender and sports level. In competition, some athletes' maximum heart rate intensity is even as high as $97 \%$. This study applied the theory of multi-source information fusion to carry out representative research on the intelligent monitoring and evaluation of the heart function of elite athletes, centering on the application needs of the monitoring of the heart function of elite athletes. This paper aims to establish a heart function testing and evaluation system for elite athletes, and to provide theoretical basis and technical support for the application research of talent selection and physical training plan formulation for elite athletes.

\section{ACKNOWLEDGMENT}

The study was supported by the grant Clinical Research Fund Project (QMSI2021L-09) of the Research Institute of medicine and Pharmcay Qiqihar.

The study was supported by the grant Scientific Research Project of Health Commission of Heilongjiang Province (202115020446).

All authors declare no potential conflict of interest related to this article 


\section{REFERENCES}

1. Badau A, Badau D, Enoiu RS, Enoiu RS. The influence of body mass of water level on cardiovascular and urinary parameters at athlete students. Revista de Chimie. 2019;70(9):3269-72.

2. Hainline B, Drezner JA, Baggish A, Harmon KG, Emery MS, Myerburg RJ, et al. Interassociation consensus statement on cardiovascular care of college student-athletes. J Am Coll Cardiol. 2016;67(25):2981-95. doi: 10.1016/j.jacc.2016.03.527

3. Drezner JA, O'Connor FG, Harmon KG, Fields KB, Asplund CA, Asif IM, et al. AMSSM Position Statement on Cardiovascular Preparticipation Screening in Athletes: Current evidence, knowledge gaps, recommendations and future directions. Br J Sports Med. 2017;51(3):153-67. doi: 10.1136/ bjsports-2016-096781.

4. Child AH. Diagnosis and Management of Marfan Syndrome. London: Springer; 2016.

5. Uzor TN, Emeahara GO. Effects of lower and upper body plyometric training on cardiovascular variables of athletes. Journal of Academy of Dental Education. 2019;15(NO 2):221-7.
6. UzorT. Effect of UBPT on cardiovascular variables and ECG of athletes. Journal of Academy of Dental Education. 2019;15(2):135-40.

7. Durando MM. Cardiovascular causes of poor performance and exercise intolerance and assessment of safety in the equine athlete. Vet Clin North Am Equine Pract. 2019;35(1):175-90. doi: 10.1016/j.cveq.2018.12.002.

8. Johri AM, Grubic N, Kuljic N, O'Connor M, Graham K, Bennett R, et al. Translation of the Canadian Cardiovascular Society/Canadian Heart Rhythm Society Cardiovascular Screening and Care of Athletes Program Into Practice. Can J Cardiol. 2019;35(7):935-9. doi: 10.1016/j.cjca.2019.03.026.

9. Hainline B, Drezner J, Baggish A, Harmon KG, Emery MS, Myerburg RJ, et al. Interassociation consensus statement on cardiovascular care of college student-athletes. Br J Sports Med. 2017;51(2):74-85. doi: 10.1136/bjsports-2016-096323.

10. Li F, Fang R, Rao L, Meng F, Zhao X. [Research progress on exosomes in diagnosis and treatment of cardiovascular diseases]. Zhejiang Da Xue Xue Bao Yi Xue Ban. 2018;47(3):320-6. Chinese. PMID: 30226336. 